\title{
Changes in Non-culprit Lesion Severity on Follow-up Coronary Angiography after Primary Percutaneous Coronary Intervention
}

\section{Primer Perkütan Koroner Girişimlerde Sorumlu Olmayan Lezyonların Kontrol Koroner Anjiyografide Değişimleri}

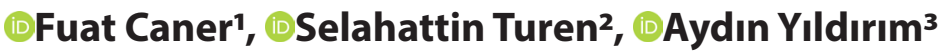 \\ 'Batman State Hospital, Department of Cardiology, Batman, Turkey \\ ${ }^{2}$ University of Health Sciences, Istanbul Mehmet Akif Ersoy Thoracic and Cardiovascular Surgery Training and Research Hospital, \\ Department of Cardiology, Istanbul, Turkey \\ ${ }^{3}$ Istanbul Medipol University, Department of Cardiology, İstanbul, Turkey
}

\begin{abstract}
Aim: Non-culprit lesion severity has often been exaggerated at the time of acute ST segment elevation myocardial infarction (STEMI). We aimed to determine changes in non-culprit lesions severity on follow-up coronary angiography (CAG) and independent predictors of these changes.

Material and Method: We retrospectively evaluated the changes in non-culprit lesion stenosis on follow-up CAG which was done within 2 months after primary percutaneous coronary intervention (P-PCl) in patients presenting with STEMI.

Results: 154 patients were included in this study and 207 nonculprit lesions (percentage diameter stenosis (PDS) $\geq 50 \%$ ) were compared using quantitative coronary analyses (QCA). Minimal lumen diameter $(1.30 \pm 0.38 \mathrm{~mm}$ vs. $1.54 \pm 0.46 \mathrm{~mm}, \mathrm{p}<0.001)$ and reference vessel diameter $(2.88 \pm 0.66 \mathrm{~mm}$ vs. $2.92 \pm 0.64 \mathrm{~mm}$, $\mathrm{p}=0.001)$ were increased significantly and PDS $(54.49 \pm 9.38$ vs. $47.5 \pm 11.17, p<0.001)$ and percentage area stenosis $(78.38 \pm 8.65$ vs. $71.29 \pm 11.84, p=<0.001$ ) were decreased significantly. There was no significant change in lesion length $(13.52 \pm 5.59 \mathrm{~mm}$ vs. $13.25 \pm 5.31$ $\mathrm{mm}, \mathrm{p}=0.078$ ). 65 (31.4\%) of these significant lesions (PDS $\geq 50 \%$ by QCA) were regressed (less than $50 \%$ ) on follow-up CAG. In multivariable analyses; current smoking, clopidogrel use after the $\mathrm{P}-\mathrm{PCl}$ and history of coronary artery disease were the independent predictors of decrease in PDS.
\end{abstract}

Conclusion: Significant exaggeration of non-culprit lesion stenosis severity occurs at the time of acute STEMI.

Keywords: Primary percutaneous coronary intervention; multivessel disease; non-culprit lesion; quantitative coronary analysis
Öz

Amaç: Akut ST segment yükselmeli miyokard enfarktüsü (STEMI) sırasında sorumlu olmayan lezyonlar sıklikla olduklarından daha ciddi görünürler. Kontrol koroner anjiyografi (KAG)'de sorumlu olmayan lezyonların şiddetindeki değişiklikleri ve bu değişikliklerin bağımsız prediktörlerini belirlemeyi amaçladık.

Gereç ve Yöntem: STEMl ile başvuran ve primer perkütan koroner girişimden (P-PKG) sonraki 2 ay içinde kontrol KAG yapılan hastalarda sorumlu olmayan lezyonlardaki değişiklikleri retrospektif olarak değerlendirdik.

Bulgular: Bu çalışmaya 154 hasta dahil edildi ve 207 (yüzde çap darlığı (YÇD) $\geq 50 \%$ ) sorumlu olmayan lezyon kantitatif koroner analizler (QCA) kullanılarak karşılaştıııldı. Minimal lümen çapı $(1,30 \pm 0,38$ mm'ye karşı 1,54 $\pm 0,46 \mathrm{~mm}, p<0,001)$ ve referans damar çapı $(2,88 \pm 0,66$ mm'ye karşı $2,92 \pm 0,64$ mm, $p=0,001)$ önemli ölçüde arttı ve YÇD $(54,49 \pm 9,38$ 'e karşı $47.5 \pm 11.17, p<0.001)$ ve yüzde alan darlığı (78.38 \pm 8.65 vs. $71.29 \pm 11.84, p=<0.001)$ anlamlı olarak azaldı. Lezyon uzunluğunda anlamlı değişiklik izlenmedi (13,52 5 ,59 mm'ye karşı $13,25 \pm 5,31 \mathrm{~mm}, \mathrm{p}=0,078$ ). Bu önemli lezyonların 65'i (\% 31.4) (QCA'ya göre YÇD $\geq \%$ 50) kontrol KAG'de geriledi (\% 50'den az). Çok değişkenli analizlerde; mevcut sigara kullanımı, P-PKG'den sonra klopidogrel kullanımı ve koroner arter hastalığı öyküsü, YÇD'deki azalmanın bağımsız prediktörleri idi.

Sonuç: Akut STEMI sırasında sorumlu olmayan lezyonlardaki darlıkların derecesi önemli ölçüde daha artmış olarak izlenmektedir.

Anahtar kelimeler: Primer perkütan koroner girişim; çoklu damar hastalığl; sorumlu olmayan lezyon; kantitatif koroner analiz 


\section{INTRODUCTION}

Acute coronary syndrome (ACS) is a continuum disease process and complete coronary occlusion in the absence of collateral perfusion results in ST-segment elevation myocardial infarction (STEMI). STEMI comprises approximately $25 \%$ to $40 \%$ of ACS presentations. ${ }^{[1,2]}$ Prompt restoration of myocardial perfusion is vital and primary percutaneous coronary intervention (P-PCI) is the preferred mode of reperfusion. ${ }^{[3,4]}$ Approximately 50\% of STEMI patients have significant stenoses in one or more non-culprit arteries ${ }^{[5,6]}$ at the time of $\mathrm{P}-\mathrm{PCl}$. Coronary flow also globally slows in acute myocardial infarction (AMI), and relief of the culprit artery stenosis by $\mathrm{PCl}$ restores flow in the non-culprit artery as well. ${ }^{[9]}$ Non-culprit stenosis severity may be exaggerated on angiographic assessment at the time of AMI ${ }^{[7,8]} \mathrm{ACS}$ are usually triggered by acute thrombosis, superimposed on a ruptured or eroded atherosclerotic plaque. ${ }^{[10,11]}$ The thrombotic response to plaque rupture is very a dynamic process may result in generation of vasoconstrictors such as thrombin, serotonin and thromboxane $A$ and often associated with vasospasm and distal embolization. ${ }^{[12]}$ Endothelial dysfunction associated with increased risk of thrombosis and abnormal vasomotor response via mediators such as prostacyclin, endothelin- 1 and decreased secretion of nitric oxide. ${ }^{[13]}$ Increased sympathetic activity has been documented during acute myocardial infarction and this may cause coronary vasoconstriction in the presence of endothelial dysfunction. Also, activation of the circulating renin-angiotensin system occur during severe ischemia. This neurohormonal activation leads to systemic and possibly to coronary vasoconstriction. ${ }^{[14,15]}$ All of these mechanisms involved in pathogenesis of ACS are possibly contributing to exaggeration of non-culprit vessel stenosis severity during STEMI. Significant stenosis has generally been defined as $>50 \%$ diameter stenosis of non-culprit artery. ${ }^{[8,9,16]}$ We performed a retrospective analysis of patients who underwent $\mathrm{P}-\mathrm{PCI}$ for STEMI with significant non-culprit lesions and had another elective coronary angiogram (CAG) within 60 days. We sought to determine changes in non-culprit vessel lesions severity and independent factors associated with these changes.

\section{MATERIAL AND METHOD}

\section{Patient population}

We reviewed data of all patients who presented with STEMI and underwent P-PCl and had an elective follow-up CAG within 2-60 days between December 2010 and July 2012 at our Hospital. This study was conducted according to the Declaration of Helsinki and approved by the Hospital Clinical Research Ethics Committee (IRB number: 2013/13). Written informed consent was obtained from all patients before the procedures. No extramural funding was used to support this work. The authors are solely responsible for the design and conduct of this study; all study analyses, the drafting and editing of the manuscript, and its final contents.

\section{Patient selection}

$>18$ year-old patients who presented with STEMI and underwent P-PCl within the first 12 hours of the onset of typical ischemic chest pain and found to have significant (visually estimated diameter stenosis of $\geq 50 \%$ on the $\mathrm{P}-\mathrm{PCl}$ ) nonculprit lesions and had an elective follow-up CAG within 2-60 days were included in this study. Patients who had non-culprit lesions with chronic total occlusion (100\% stenosis), instent stenosis, CABG to non-culprit arteries and non-matching projections $\left(>5^{\circ}\right.$ difference in any plane between $\mathrm{P}-\mathrm{PCl}$ and follow-up (AG) were excluded from this study. Patients who had follow-up CAG done for ACS were also excluded from this study.

\section{Procedural details}

Primary $\mathrm{PCl}$ was performed by the percutaneous femoral approach and all patients received a chewable $300 \mathrm{mg}$ aspirin and clopidogrel $600 \mathrm{mg}$ loading dosage before the procedure. The culprit lesion was identified as the site of acute occlusion or impaired Thrombolysis in Myocardial Infarction 3 flow. ${ }^{[17]}$ Non-culprit lesions were defined as lesions in an artery other than the infarct related artery with smooth angiographic borders and no associated thrombus. Heparin (100 IU/kg I.V.) was administered when the coronary anatomy was defined. $\mathrm{P}-\mathrm{PCl}$ was performed only for culprit lesions. After angioplasty, all patients were admitted to the coronary care unit, where $100 \mathrm{mg}$ aspirin and $75 \mathrm{mg}$ clopidogrel were continued in all patients. The use of glycoprotein Ilb/Illa inhibitors was up to the discretion of the operator.

\section{Quantitative coronary analysis (QCA) measurements}

All $\mathrm{P}-\mathrm{PCl}$ angiograms were reviewed by two experienced operators to find those patients who had a significant nonculprit lesion (visually estimated diameter stenosis of $\geq 50 \%$ ). Angiographic images before any intracoronary nitrates were administered were used for comparisons. Coronary angiography (Siemens Artis Zee Ceiling, Erlangen, Germany) was performed in multiple orthogonal projections and nonculprit lesion severity was analyzed with validated QCA 2D coronary quantification software (Scientific QCA Analysis, Siemens, Erlangen, Germany). ${ }^{[18]}$ The contrast filled catheter tip was traced and used for calibration. End-diastolic images in the least foreshortened view were used for the quantitative measurement. Projection that showed the most critical stenosis was chosen and orthogonal projection was identified. Average of the measurements from these 2 projections was obtained. Analysis was performed by two experienced operators and the average of the two was calculated. Interobserver agreements were $94 \%$ and $91 \%$ for MLD and PDS, respectively.

\section{Data Collection and Definitions}

Patients' demographic and clinical characteristics were obtained from patients' charts and electronic medical record system. Following information was gathered: age, gender, co-morbidities and risk factors for coronary artery disease (CAD) (smoking history, family history, diabetes mellitus, 
hypertension, and hyperlipidemia), history of CAD (previous $\mathrm{MI}, \mathrm{PCl}$ and $\mathrm{CABG}$ ), time elapsed to follow-up CAG, MI territory, angiographic and procedural details (culprit lesion, non-culprit lesions, PTCA, tirofiban and stent use on P-PCl) and medications on PPCl and follow-up CAG. Angiographic data of the patients were obtained from catheter laboratory records and electronic medical record system. Angiographic images of primary PCI and follow-up CAG were used for QCA. Minimal lumen diameter (MLD), percentage diameter stenosis (PDS), percentage area stenosis (PAS), reference vessel diameter (RVD) and lesion length (LL) were the parameters assessed by QCA.

MLD, RVD and LL defined as the smallest lumen diameter in the segment of interest, the averaged diameter of the coronary artery assumed without atherosclerotic disease and length of the stenosis as measured by 2 points where the coronary margins change direction creating a shoulder between the angiographically normal subsegment and the diseased subsegment respectively. Percentage diameter stenosis and percentage area stenosis are calculated as follows: $100 \% \mathrm{X}$ (RVD-MLD)/RVD and $100 \% \mathrm{X}\left(\mathrm{RVD}^{2}-\mathrm{MLD}^{2}\right) / \mathrm{RVD}^{2}$ respectively.

STEMI defined as ST segment elevation of at least $1 \mathrm{~mm}$ in two or more contiguous leads ( $2 \mathrm{~mm}$ for V1-V3) or new-onset left bundle branch block..$^{[3]}$

Lesion not responsible for the acute STEMI is defined as nonculprit lesion. Significant lesion is defined as $>50 \%$ diameter stenosis of artery by QCA.

The primary goal was to assess the changes in non-culprit vessel lesion severity by QCA and secondary goal was to assess the independent predictors of these changes.

\section{Statistical analysis}

Continuous variables are expressed as means $\pm S D$, and categorical variables are expressed as percentages. Univariable analyses (using the chi-square or the Fisher exact test and McNemar test for paired categorical variables and the $t$ test or Mann-Whitney $U$ test for continuous variables) were performed to identify demographics, baseline clinical characteristics, and peri-procedural variables associated with changes in non-culprit vessel lesion severity (MLD, RVD, PDS, PAS and LL). Angiographic data between the two procedures were compared using paired t tests and changes in medications were compared using McNemar test. Uni-and multivariable predictors of changes in in non-culprit vessel lesion severity were assessed by logistic regression analysis and odds-ratios $(\mathrm{OR})$ are reported. A backward stepwise multivariable logistic regression model was carried out to assess the independent relationship between variables (demographics, baseline clinical characteristics and changes in medications) and changes in non-culprit vessel QCA parameters. Variables exhibiting a $P$ value of $<0.1$ in the univariable analysis were entered into the multivariable logistic regression model. For all tests, 2 -sided $P$ values $<0.05$ were considered as significant. Statistical analysis was performed using the Statistical Package for the Social Sciences (SPSS) version 17.0 for Windows (SPSS Inc, Chicago, Illinois, USA).

\section{RESULTS}

A total of 1442 consecutive patients who presented with STEMI and underwent P-PCI between December 2010 and July 2012 at a single tertiary care center were retrospectively reviewed. There were 749 (51.9\%) patients with operatorreported multi-vessel disease. Initially, 195 patients were identified who had elective follow-up CAG within 2-60 days after primary $\mathrm{PCl}$ for non-culprit lesion $\mathrm{PCl}$ or before scheduled coronary artery by-pass graft (CABG) surgery. Six patients had instent stenoses, 2 patient had CABG to nonculprit vessels, 4 patients had chronic total occlusion $(100 \%$ stenosis) and 29 patients had non-matching projections ( $>5^{\circ}$ difference in any plane). After exclusion of those 41 patients, final study population consisted of 154 patients. Of those 154 patient included in this study had total of 207 significant non-culprit lesions.

Demographics and Baseline Clinical characteristics of the study population are shown in Table 1. Mean age was $56.1 \pm 9.5(33-88)$ and $131(85.1 \%)$ of the patients were male. TIMI 3 flow was achieved in all patients after P-PCI. Sixty-four (41.5\%) patients had acute anterior MI. Time to follow-up CAG was $25.5 \pm 14.2$ days $(2-60)$.

\begin{tabular}{lc} 
Table 1. Patients' Demographics and Baseline Clinical characteristics \\
$\begin{array}{l}\text { Demographics and Baseline Clinical } \\
\text { characteristics }\end{array}$ & $\begin{array}{c}\text { Study population } \\
\text { (n=154) }\end{array}$ \\
\hline Age (yrs) & $56.1 \pm 9.5(33-88)$ \\
Male & $131(85.1 \%)$ \\
Diabetes mellitus & $42(27.3 \%)$ \\
Hypertension & $74(48.1 \%)$ \\
Current smoker & $99(64.3 \%)$ \\
Hyperlipidemia & $83(53.9 \%)$ \\
Family history of CAD & $49(31.8)$ \\
History of CAD & $46(29.8 \%)$ \\
Previous MI & $25(16.2 \%)$ \\
Previous PCI & $19(12.3 \%)$ \\
Previous CABG & $2(1.3 \%)$ \\
Anterior MI & $64(41.5 \%)$ \\
Time to follow up CAG (day) & $25.5 \pm 14.2(2-60)$ \\
Culprit Vessel & \\
LAD & $64(41.5 \%)$ \\
CX & $34(22.1 \%)$ \\
RCA & $56(36.4 \%)$ \\
Non-Culprit Vessel & \\
LAD & $79(38.2 \%)$ \\
CX & $53(25.6 \%)$ \\
RCA & $75(36.2 \%)$ \\
Number of Non-Culprit Vessels & \\
1 Vessel & $112(72.7 \%)$ \\
3 Vessel & $33(21.4 \%)$ \\
\hline CABG: coronary artery bypass graft surgery, CAD: coronary artery disease, Cx: circumflex artery, LAD: \\
percutaneous transling, Ml myocardial infarction, PCl: percutaneous coronary intervention, PTCA: \\
\hline
\end{tabular}


Angiographic and peri-procedural chracteristics are shown in Table 2. Tirofiban was used in 66 (42.9\%) patients and 145 (94.1\%) patients underwent stent placement on P-PCI. There were significant differences in all medications between at the time of P-PCI and follow-up CAG with very high use of standard optimal medical therapy.

\begin{tabular}{|c|c|c|c|}
\hline & P-PCI & Follow-up CAG & p Value \\
\hline \multicolumn{4}{|l|}{ Lesion Characteristics } \\
\hline MLD (mm) & $1.30 \pm 0.38$ & $1.54 \pm 0.46$ & $<0.001$ \\
\hline $\operatorname{RVD}(\mathrm{mm})$ & $2.88 \pm 0.66$ & $2.92 \pm 0.64$ & $=0.001$ \\
\hline PDS (\%) & $54.49 \pm 9.38$ & $47.5 \pm 11.17$ & $<0.001$ \\
\hline PAS (\%) & $78.38 \pm 8.65$ & $71.29 \pm 11.84$ & $<0.001$ \\
\hline Lesion Length (mm) & $13.52 \pm 5.59$ & $13.25 \pm 5.31$ & 0.078 \\
\hline PDS ( $\geq 50 \%)$ & $157(75.8 \%)$ & $92(44.4 \%)$ & $<0.001$ \\
\hline \multicolumn{4}{|l|}{ Procedural details } \\
\hline Stent & $145(94.1 \%)$ & & \\
\hline PTCA & $9(5.9 \%)$ & & \\
\hline Tirofiban & $66(42.9 \%)$ & & \\
\hline \multicolumn{4}{|l|}{ Medications } \\
\hline ASA & $24(15.6 \%)$ & $152(98.7 \%)$ & $<0.001$ \\
\hline Clopidogrel & $8(5.2 \%)$ & $151(98.1 \%)$ & $<0.001$ \\
\hline Beta- blocker & $12(7.8 \%)$ & $150(97.4 \%)$ & $<0.001$ \\
\hline ACE inhibitor or ARB & $34(22.1 \%)$ & $143(92.9 \%)$ & $<0.001$ \\
\hline Calcium-channel blocker & $8(5.2 \%)$ & $21(13.6 \%)$ & 0.002 \\
\hline Statin & $13(8.4 \%)$ & $148(96.1 \%)$ & $<0.001$ \\
\hline Nitrate & $3(1.9 \%)$ & $36(23.4 \%)$ & $<0.001$ \\
\hline
\end{tabular}

ACE: angiotensin-converting-enzyme, ARB: angiotensin receptor blocker, ASA: acetylsalicylic acid,CAG coronary angiography, MLD: minimal lumen diameter, PAS: percentage area stenosis, PDS: percentage diameter stenosis, P-PCl: primary percutaneous coronary intervention, PTCA: percutaneous transluminal coronary angioplasty, RVD: reference vessel diameter.

\section{Changes in non-culprit lesion severity by QCA}

MLD (1.30 $\pm 0.38 \mathrm{~mm}$ vs. $1.54 \pm 0.46 \mathrm{~mm}, \mathrm{p}=<0.001)$ and RVD $(2.88 \pm 0.66 \mathrm{~mm}$ vs. $2.92 \pm 0.64 \mathrm{~mm}, \mathrm{p}=0.001)$ were increased significantly and PDS (54.49 \pm 9.38 vs. $47.5 \pm 11.17, \mathrm{p}=<0.001)$ and PAS (78.38 \pm 8.65 vs. 71.29 $\pm 11.84, p=<0.001)$ were decreased significantly on follow-up CAG compared to P-PCI. There was no significant change in lesion length $(13.52 \pm 5.59$ $\mathrm{mm}$ vs. $13.25 \pm 5.31 \mathrm{~mm}, \mathrm{p}=0.078)$.

Of these 207 non-culprit lesions, MLD and RVD showed absolute increase in 172 (83.1\%) and 128 (61.8\%) lesions, respectively. Number of significant non-culprit lesions (PDS $\geq 50 \%$ by QCA) was $157(75.8 \%)$ at the time of $\mathrm{P}-\mathrm{PCl}$ and was declined to $92(44.4 \%)$ on follow-up CAG. This means that severity of the stenosis in 65 (41.4\%) of the non-culprit lesions were exaggerated significantly at the time of the $\mathrm{P}-\mathrm{PCl}$.

\section{Predictors of changes in non-culprit lesion severity}

None of the clinical and demographic variables were significantly associated with increase in RVD in univariable analyses. Variables (hypertension, hyperlipidemia, current smoking, history of CAD and clopidogrel use after the P-PCI) exhibiting a $P$ value of $<0.1$ in the univariable analyses for the increase in MLD and decrease in PDS were entered into the model for multivariable analyses. In multivariable analyses (Table 3); current smoking [Odds Ratio (OR): 10.36, 95\% Confidence Interval (Cl): 4.06 - 26.41, p <0.001], history of CAD [OR: $0.21,95 \% \mathrm{Cl}: 0.084-0.559, \mathrm{p}=0.002$ ] and clopidogrel use after the P-PCI [OR: 20.0, 95\% Cl: 2.34 - 170.53, p=0.006] were found to be associated with the increase in MLD. Likewise, current smoking [OR: 10.42, 95\% Cl: 4.09 - 26.53, p <.001], history of CAD [OR: $0.26,95 \% \mathrm{Cl}: 0.098-0.689, \mathrm{p}=0.007]$ and clopidogrel use after the P-PCI [OR: 26.63, 95\% Cl: 3.06 - 231.30, $p=0.003$ ] were found to be associated with decrease in PDS.

\begin{tabular}{|c|c|c|}
\hline Variable & Odds ratio $(95 \% \mathrm{Cl})$ & P-value \\
\hline \multicolumn{3}{|l|}{ Predictors of changes in MLD } \\
\hline Current smoking & $10.36(4.06-26.41)$ & $<0.001$ \\
\hline History of CAD & $0.21(0.084-0.559)$ & $=0.002$ \\
\hline Clopidogrel use after P-PCI & $20.0(2.34-170.53)$ & $=0.006$ \\
\hline \multicolumn{3}{|l|}{ Predictors of changes in PDS } \\
\hline Current smoking & $10.42(4.09-26.53)$ & $<0.001$ \\
\hline History of CAD & $0.26(0.098-0.689)$ & $=0.007$ \\
\hline Clopidogrel use after P-PCI & $26.63(3.06-231.30)$ & $=0.003$ \\
\hline
\end{tabular}

\section{DISCUSSION}

Approximately $50 \%$ of STEMI patients have significant stenoses in one or more non-culprit arteries ${ }^{[5,6]}$ at the time of P-PCl. Outcomes and best treatment strategies (complete vs. culprit lesion only) of the patients presenting with STEMI and multivessel disease has been investigated in many studies. But only in a few studies changes in the culprit or non-culprit lesions severity assessed by QCA have been reported. Exaggeration of non-culprit lesion stenosis severity might occur at the time of ACS.

The results of this study show that exaggeration of non-culprit lesion stenosis severity occurs at the time of acute STEMI. MLD and RVD were increased significantly and PDS and PAS were decreased significantly on follow-up CAG which was done in non-acute settings. There was no significant change in lesion length. MLD and RVD showed absolute increase in 172 (83.1\%) and $128(61.8 \%)$ lesions, respectively. Number of significant non-culprit lesions (percentage diameter stenosis $\geq 50 \%$ by QCA) was 157 (75.8\%) at the time of P-PCI and was declined to $92(44.4 \%)$ on follow-up CAG. This means that severity of the stenosis in $65(41.4 \%)$ of the non-culprit lesions were exaggerated at the time of the $\mathrm{P}-\mathrm{PCl}$. Independent predictors of both increase in MLD and decrease in percentage diameter stenosis were; smoking, history of CAD and clopidogrel use after the $\mathrm{P}-\mathrm{PCl}$.

There was no significant change in lesion length in our study. In a study by Sahin et al. ${ }^{[19]} 58$ patients with acute ST-segment elevation myocardial infarction (STEMI) were evaluated for changes in diameter of the infarct-related artery (IRA) during primary $\mathrm{PCl}$ and after an average of 3 days. CAG was performed 
on presentation and TIMI 3 flow was achieved either by simple balloon dilatation and/or thrombus aspiration. Lesion length, RVD, MLD, mean vessel diameter (meanD), and area of stenosis were compared during P-PCl and follow-up CAG. They also found that there was no significant change in lesion length.

RVD was increased significantly on follow-up CAG in our study similar to the reported by Sahin et al. ${ }^{[19]}$ However, Hanratty et al ${ }^{[8]}$ and Cristea et al. ${ }^{[20]}$ found that there was no change in RVD. Hanratty et al ${ }^{[8]}$ included 48 patients with 59 non-culprit lesions suitable for analysis in their study. Between infarct and non-infarct angiograms there was a significant change in minimal lumen diameter $(1.53 \pm 0.51 \mathrm{~mm}$ vs. $1.78 \pm 0.65 \mathrm{~mm}$, $p<0.001)$ and percentage diameter stenosis $(49.3 \pm 14.5 \%$ vs. $40.4 \pm 16.6 \%, p<0.001$ ) of the nonculprit lesion without significant change in reference segment diameter. Twenty-one percent of patients had lesions $>50 \%$ at AMI that were $<50 \%$ at non-AMI angiography. Infarct versus non-infarct setting was the only significant independent predictor of change in non-culprit stenosis. PDS was decreased significantly in our study consistent with the observations of Hanratty et al. ${ }^{[8]}$ and Sahin et al. ${ }^{[19]}$ MLD was increased and PDS was decreased significantly in our study on follow-up CAG. Hanratty et al. ${ }^{[8]}$ and Sahin et al. ${ }^{[19]}$ also reported similar significant changes in MLD and PDS. We also found that current smoking, history of CAD and clopidogrel use after the P-PCl were independent predictors of both increase in MLD and decrease in PDS in multivariable analysis.

Natural progression of coronary artery disease involves two distinct processes. First, fixed and almost irreversible process that causes gradual luminal narrowing slowly over decades (atherosclerosis). Second, a dynamic and potentially reversible process that causes rapid coronary occlusion (thrombosis or vasospasm, or both). Thus, symptomatic coronary lesions contain a variable mix of chronic atherosclerosis and acute thrombosis but, because the exact nature of the mix is unknown in the individual patient, the term atherothrombosis is frequently used. Generally, atherosclerosis predominates in lesions responsible for chronic stable angina, whereas thrombosis constitutes the critical component of culprit lesions responsible for the ACS. ${ }^{[11,12,21,22]}$

Individuals using clopidogrel after the $\mathrm{P}-\mathrm{PCl}$ were more likely to have increase in MLD and decrease in percentage diameter stenosis, OR (Odds Ratio): 20.0 ( $95 \%$ Cl: $2.34-170.53, p=0.006$ ) and OR: 26.63 (95\% Cl: $3.06-231.30, p=0.003)$, respectively. This significant improvement in non-culprit vessel stenosis with the use of clopidogrel can be due to the inhibition of platelet functions which result in inhibition of this second dynamic and reversible process of atherothrombosis at the time of $\mathrm{P}-\mathrm{PCl}$ as described above.

Individuals with a current smoking history were more likely to have increase in MLD and decrease in percentage diameter stenosis, OR: 10.36 (95\% Cl: $4.06-26.41, \mathrm{p}<0.001)$ and 10.42 times (95\% Cl: $4.09-26.53, p<.001$ ), respectively. Cigarette smoking plays a direct role by constricting coronary arteries through nicotine-mediated action on alpha-adrenergic receptors and by induction of endothelial dysfunction by nicotine and oxidizing chemicals. ${ }^{[23,24]}$ Therefore, smoking is more likely to cause rapid and reversible coronary occlusion in patients with ACS rather than the fixed stenosis.

Individuals with a history of CAD were less likely to have increase in MLD and decrease in percentage diameter stenosis, OR: 0.21 (95\% Cl: $0.084-0.559, \mathrm{p}=0.002)$ and 0.26 (95\% Cl: 0.098 $0.689, p=0.007)$, respectively. Individuals with a known history of CAD are more likely to have predominantly atherosclerotic lesions. These are generally fixed fibroproliferative and hardly reversible lesions that cause slow gradual stenosis.

\section{CONCLUSION}

Exaggeration of non-culprit lesion stenosis severity occurs at the time of acute STEMI. Deferring the revascularization decision making and further evaluation of these lesions with FFR or intravasküler ultrason may result in more accurate evaluation of the lesions and prevent unnecessary $\mathrm{PCl}$.

\section{Limitations}

Retrospective and monocentric characters are the limitations of our study.

\section{ETHICAL DECLARATIONS}

Ethics Committee Approval: Study was approved by the Republic of Turkey Ministry of Health, University Of Health Sciences, Istanbul Mehmet Akif Ersoy Thoracic and Cardiovascular Surgery Training and Research Hospital Clinical Research Ethics Committee (IRB number: 2013/13).

Informed Consent: Because the study was designed retrospectively, no written informed consent form was obtained from patients.

Referee Evaluation Process: Externally peer-reviewed.

Conflict of Interest Statement: The author(s) declared no potential conflicts of interest with respect to the research, authorship, and/or publication of this article.

Financial Disclosure: The authors declared that this study has received no financial support.

Author Contributions: All of the authors declare that they have all participated in the design, execution, and analysis of the paper, and that they have approved the final version.

\section{REFERENCES}

1. Mandelzweig L, Battler A, Boyko V, et al. The second Euro Heart Survey on acute coronary syndromes: characteristics, treatment, and outcome of patients with ACS in Europe and the Mediterranean Basin in 2004. Eur Heart J. 2006;27:2285-93.

2. Yeh RW, Sidney S, Chandra M, et al. Population trends in the incidence and outcomes of acute myocardial infarction. N Engl J Med. 2010;362:215565.

3. Steg PG, James SK, Atar D, et al. ESC Guidelines for the management of acute myocardial infarction in patients presenting with ST-segment elevation. Eur Heart J. 2012;33(20):2569-619. 
4. O'Gara PT, Kushner FG, Ascheim DD, et al. 2013 ACCF/AHA guideline for the management of ST-elevation myocardial infarction: a report of the American College of Cardiology Foundation/American Heart Association Task Force on Practice Guidelines. Circulation 2013;127:e362-425.

5. Widimsky P, Holmes DR Jr. How to treat patients with ST-elevation acute myocardial infarction and multi-vessel disease? Eur Heart J 2011;32:396403.

6. Cavender MA, Milford-Beland S, Roe MT, Peterson ED, Weintraub WS, Rao SV. Prevalence, predictors, and in-hospital outcomes of non-infarct artery intervention during primary percutaneous coronary intervention for ST-segment elevation myocardial infarction (from the National Cardiovascular Data Registry). Am J Cardiol 2009;104:507-13.

7. Kahn JK. Evidence for dynAMEc coronary vasoconstriction of non-infarct vessels during acute myocardial infarction. Cathet Cardiovasc Diagn. 1995;36(4):371-3.

8. Hanratty CG, Koyama Y, Rasmussen HH, Nelson Gl, Hansen PS, Ward MR. Exaggeration of nonculprit stenosis during acute myocardial infarction: implication for immediate multivessel revascularization. J Am Coll Cardiol. 2002;40:911-6.

9. Gibson CM, Ryan KA, Murphy SA, et al. Impaired coronary blood flow in nonculprit arteries in the setting of acute myocardial infarction. The TIMI Study Group.Thrombolysis In Myocardial Infarction. J Am Coll Cardiol 1999;34: 974-82.

10. Glass CK, Witztum JL. Atherosclerosis: the road ahead. Cell 2001;104:503516.

11. Libby P. Current concepts of the pathogenesis of the acute coronary syndromes. Circulation 2001;104:365-372

12. Falk E, Shah PK, Fuster V. Atherothrombosis and thrombosis-prone plaques. In: Fuster V, Alexander RW, O'Rourke RA, et al., eds. Hurst's the Heart, 2004. New York: McGraw-Hill, pp. 1123-39.

13. Bogaty P, Hackett D, Davies G, Maseri A. Vasoreactivity of the culprit lesion in unstable angina. Circulation 1994;90:5-11.

14. Remme WJ, Kruijssen DA, Look MP, Bootsma, de Leeuw PW: Systemic and cardiac neuroendocrine activation and severity of myocardial ischemia in humans. J Am Coll Cardiol 1994;23:82-91

15. Slavíková J, Kuncová J, Topolcan O. Plasma catecholamines and ischemic heart disease. Clin Cardiol 2007;30:326-330.

16. Wald DS, Morris JK, Wald NJ, et al. Randomized trial of preventive angioplasty in myocardial infarction. N Engl J Med. 2013 Sep 19;369 (12):1115-23.

17. Chesebro JH, Knatterud G, Roberts R, et al. Thrombolysis in Myocardial Infarction (TIMI) Trial. Phase I: a comparison between intravenous tissue plasminogen activator and intravenous streptokinase. Clinical findings through hospital discharge. Circulation 1987;76:142-5.

18. Salvatore Davide Tomasello, Luca Costanzo, Alfredo Ruggero Galassi. Quantitative Coronary Angiography in the Interventional Cardiology, Advances in the Diagnosis of Coronary Atherosclerosis, Prof.Suna Kirac (Ed.), 2011. ISBN: 978-953-307-286-9, InTech, Available from: http://www.intechopen.com/books/advances-in-the-diagnosis-ofcoronary-atherosclerosis/quantitativecoronary-angiography-in-theinterventional-cardiology

19. Sahin M, Demir S, Kocabay G, et al. Coronary vessel diameters during and after primary percutaneous coronary artery intervention. Herz 2014;39(4):515-21.

20. Cristea E, Stone GW, Mehran R et al. Changes in reference vessel diameter in ST-segment elevation myocardial infarction after primary percutaneous coronary intervention: implications for appropriate stent sizing. Am Heart J 2011;162(1):173-7.

21. Libby P. Inflammation in atherosclerosis. Nature 2002;420: 868-74.

22. Davies MJ. The pathophysiology of acute coronary syndromes. Heart 2000;83:361-66.

23. Nicod P, Rehr R, Winniford MD, Campbell WB, Firth BG, Hillis LD. Acute systemic and coronary hemodynamic and serologic responses to cigarette smoking in long term smokers with atherosclerotic coronary artery disease. J Am Coll Cardiol 1984;4(5):964-71.

24. Puranik R, Celermajer DS. Smoking and endothelial function. Progress in Cardiovascular Diseases 2003;45(6):443-58. 